Polymer Journal, Vol. 38, No. 12, pp. 1237-1244 (2006)

(C)2006 The Society of Polymer Science, Japan

\title{
Photocrosslinking System Using Highly-Functionalized Epoxy Crosslinkers Having Degradable Property
}

\author{
Haruyuki OKamura, Kazuo Shin, and Masamitsu ShIRAI ${ }^{\dagger}$ \\ Department of Applied Chemistry, Osaka Prefecture University, 1-1 Gakuen-cho, Sakai 599-8531, Japan
}

(Received April 7, 2006; Accepted September 22, 2006; Published November 2, 2006)

\begin{abstract}
Multifunctional crosslinkers having two, three, four and six functionalities were synthesized using a convergent method and were applied to a photocrosslinking system having thermally degradable properties. The multifunctional crosslinkers contained epoxy units and tertiary ester linkages. When the blended films of epoxides/poly( $p$-vinylphenol) with a photoacid generator were irradiated and followed by baking at relatively lower temperatures $\left(<100^{\circ} \mathrm{C}\right)$, the films became insoluble in solvents. Heating conditions strongly affected the insoluble fraction of the blends. Insoluble fraction of the blended films increased with the number of the epoxy unit of a molecule. The crosslinked films became soluble after prolonged bake at relatively higher treatments $\left(>120^{\circ} \mathrm{C}\right)$. The reaction pathway of the blended system was studied by in situ FT-IR measurements. [doi:10.1295/polymj.PJ2006007]

KEY WORDS Photocrosslinking / Decrosslinking / Thermal Degradation / Multifunctional / Epoxide / Photoacid Generator /
\end{abstract}

Reworkable resins which are easily removable after use are getting more important in terms of environmental aspects. In this point of view, some thermosets which are thermally or chemically degradable under a given condition have been extensively studied. ${ }^{1-18} \mathrm{We}$ have previously reported the photocurable epoxy resins which can be re-dissolved in solvents by thermal treatments. ${ }^{12-18}$ The resins consist of epoxy moieties and tertiary ester linkages. Epoxy moieties acted as photocrosslinkable units by photo-induced acid catalyzed polymerization. Tertiary ester linkages were thermally cleavable units by heating to produce carboxylic acids and alkenes. The network was destroyed by the scission of tertiary ester linkages. In practical point of view, reactivity, sensitivity, thermal or chemical stability, and re-dissolution property of the polymers must be improved. Multifunctional epoxides are expected to show higher reactivity and sensitivity compared to mono- and difunctional epoxides. We have reported that trifunctional epoxide/poly ( $p$-vinylphenol) (PVP) blended system works as a reworkable resin and the sensitivity of the system is higher than the difunctional epoxide/PVP blended system. ${ }^{18}$

In this paper, we report the synthesis of novel multifunctional epoxides having tertiary ester linkages. The multifunctional epoxides were synthesized by a convergent technique, where two or three molecules having both epoxy unit and tertiary ester unit in a molecule were linked together via another molecule. The multifunctional epoxides were used as crosslinkers of the system that has photocrosslinking and de-crosslinking properties. The system is a blend of PVP, the crosslinker, and a photoacid generator. The concept of the present system is shown in Figure 1. On irradiation, network formation occurs by the photoinducedacid catalyzed reaction of the epoxy moieties of the crosslinker and PVP. Thermal treatment of the crosslinked polymers induces the cleavage of the tertiary ester linkages. Insolubilization and dissolution properties of the blended films of multifunctional epoxide and PVP were discussed in terms of the structure of the crosslinkers and baking conditions. A reaction mechanism was investigated by in situ FT-IR measurements.

\section{EXPERIMENTAL}

\section{Materials}

1,3,5-Trimethylbenzene, 1,4-bis(bromomethyl)benzene, 4-hydroxybenzoic acid, 5-hydroxyisophthalic acid, $N$-bromosuccinimide, and $\alpha$-terpineol were obtained from Tokyo Kasei and used as received. Poly( $p$-vinylphenol) (PVP) $\left(M_{\mathrm{n}}=8000, M_{\mathrm{w}} / M_{\mathrm{n}}=1.1\right)$ and OXONE, monopersulfate compound $\left(2 \mathrm{KHSO}_{5} \cdot\right.$ $\mathrm{KHSO}_{4} \cdot \mathrm{K}_{2} \mathrm{SO}_{4}$ ) were purchased from Aldrich. Other solvents and reagents were purchased and used as received. 9-Fluorenylideneimino $p$-toluenesulfonate (FITS) was prepared according to the method described elsewhere. ${ }^{19}$ 1,3,5-Tris(bromomethyl)ben$z^{2} e^{20}$ was prepared by bromination of 1,3,5-trimethylbenzene using $N$-bromosuccinimide and purified by recrystallization from hexane before use. 4-Allyoxybenzoic acid was synthesized by the reaction of 4-hydroxybenzoic acid with allyl bromide as descried elsewhere. ${ }^{21}$ 5-Allyoxyisophthalic acid was synthesized by sequential transformation of 5-hydroxyisophthalic

${ }^{\dagger}$ To whom correspondence should be addressed (Tel/Fax: +81-72-254-9292, E-mail: mshirai@chem.osakafu-u.ac.jp). 


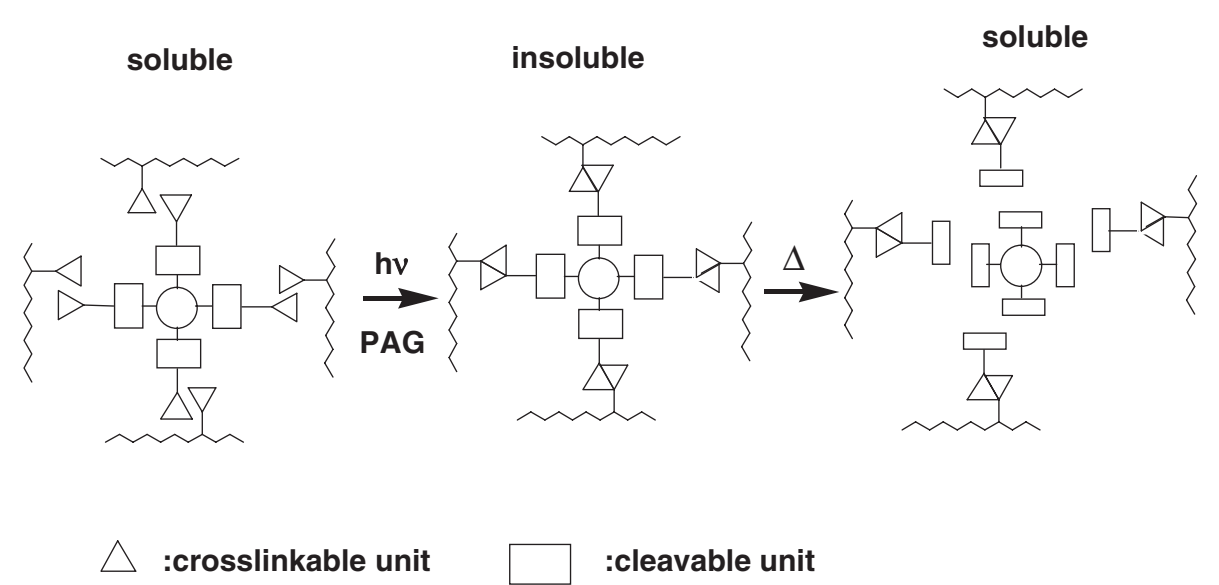

Figure 1. Concept of photocrosslinkable system having thermally degradable property.

acid into dimethyl 5-hydroxyisophthalate ${ }^{22}$ and dimethyl 5-allyloxyisophthalate. ${ }^{21}$ The target compound was obtained by hydrolysis of methyl ester moieties in dimethyl 5-allyloxyisophthalate. Transformation of 4-allyoxybenzoic acid and 5-allyoxyisophthalic acid into corresponding acid chloride $\mathbf{1 a}$ and $\mathbf{1 b}$ was performed using an excess amount of thionyl chloride and catalytic amount of $\mathrm{N}, \mathrm{N}$-dimethylformamide by heating at $60^{\circ} \mathrm{C}$ for $3 \mathrm{~h}$. The excessive thionyl chloride was evaporated and the product was used without further purification.

\section{Synthesis of Crosslinkers}

Crosslinkers were synthesized as shown in Scheme 1.

1-Methyl-1-(4-methylcyclohex-3-enyl)ethyl p-allyloxybenzoate $(2 a)$. To a cold $\left(<5^{\circ} \mathrm{C}\right)$ solution of $\alpha$ terpineol $(19.5 \mathrm{~g}, 126 \mathrm{mmol})$ and 4-dimethylaminopyridine $(1.00 \mathrm{~g}, 8.17 \mathrm{mmol})$ in a mixture of anhydrous pyridine $(40 \mathrm{~mL})$ was slowly added a solution of $22.6 \mathrm{~g}(115 \mathrm{mmol})$ of 4-allyloxybenzoyl chloride (1a) in $20 \mathrm{~mL}$ of chloroform. The mixture was stirred at $20^{\circ} \mathrm{C}$ for $147 \mathrm{~h}$ and then thoroughly washed with $2 \mathrm{~N} \mathrm{HCl}$. The organic phase was separated and washed with saturated sodium bicarbonate solution and then with water. The organic layer was dried over anhydrous $\mathrm{MgSO}_{4}$. The product was purified by column chromatography (silica gel, eluent: ethyl acetate/hexane $=1: 3)$ to obtain colorless liquid; yield $25.0 \mathrm{~g}$ (69\%). ${ }^{1} \mathrm{H}$ NMR $\left(270 \mathrm{MHz}, \mathrm{CDCl}_{3}\right) \delta 8.01(\mathrm{~d}, 2 \mathrm{H}$, aromatic), $6.91(\mathrm{~d}, 2 \mathrm{H}$, aromatic), $5.97(\mathrm{~m}, 1 \mathrm{H}$, allyl $\mathrm{C}=\mathrm{CH}-), 4.58\left(\mathrm{~d}, 2 \mathrm{H}, \mathrm{CH}_{2}=\mathrm{C}-\right), 5.32(\mathrm{~s}, 1 \mathrm{H}, \mathrm{C}=$ $\mathrm{CH}-$ ), 5.28 (q, $\left.2 \mathrm{H},-\mathrm{CH}_{2} \mathrm{O}\right), 1.16-2.11(\mathrm{~m}, 16 \mathrm{H}, \mathrm{CH}$, $\mathrm{CH}_{2}, \mathrm{CH}_{3}$ ). Anal. Calcd for $\mathrm{C}_{20} \mathrm{H}_{26} \mathrm{O}_{3}: \mathrm{C} 76.40, \mathrm{H}$ 8.33. Found: C 76.06, H 8.03.

5-Allyloxy-1,3-benzenedicarboxylic acid bis [1-methyl-1-(4-methylcyclohex-3-enyl)ethyl] ester (2b). The procedure for the synthesis of $\mathbf{2 a}$ was followed using $\alpha$-terpineol (31.2 g, $203 \mathrm{mmol})$, 4-dimethylaminopyri- dine $(1.00 \mathrm{~g}, 8.17 \mathrm{mmol})$, anhydrous pyridine $(50 \mathrm{~mL})$, and a chloroform solution $(30 \mathrm{~mL})$ of $p$-allyloxyisophthaloyl chloride (1b) (17.5 g, $67.5 \mathrm{mmol})$. The reaction was carried out at $50^{\circ} \mathrm{C}$ for $5 \mathrm{~d}$. The product was purified by column chromatography (silica gel, eluent: ethyl acetate/hexane $=1: 6$ ) to obtain colorless liquid; yield $25.9 \mathrm{~g}(78 \%) .{ }^{1} \mathrm{H}$ NMR $(270 \mathrm{MHz}$, $\left.\mathrm{CDCl}_{3}\right) \delta 8.25(\mathrm{~s}, 1 \mathrm{H}$, aromatic), $7.74(\mathrm{~d}, 2 \mathrm{H}$, aromatic), $5.97(\mathrm{~m}, 1 \mathrm{H}$, allyl $\mathrm{C}=\mathrm{CH}-), 5.43(\mathrm{~s}, 2 \mathrm{H}, \mathrm{C}=$ $\mathrm{CH}-), 5.29\left(\mathrm{~m}, 2 \mathrm{H}, \mathrm{C}=\mathrm{CH}_{2}-\right), 4.60\left(\mathrm{~d}, 2 \mathrm{H},-\mathrm{CH}_{2} \mathrm{O}\right)$, 1.29-2.11 (m, 32H, CH, $\left.\mathrm{CH}_{2}, \mathrm{CH}_{3}\right)$. Anal. Calcd for $\mathrm{C}_{31} \mathrm{H}_{42} \mathrm{O}_{5}$ : C 75.27, H 8.56. Found: C 75.31, H 8.62.

1-Methyl-1-(4-methylcyclohex-3-enyl)ethyl 4-hydoxybenzoate (3a). Under argon atmosphere, palladium(II) acetate $(100 \mathrm{mg}, 0.45 \mathrm{mmol})$, triphenylphosphine $(200 \mathrm{mg}, 0.76 \mathrm{mmol})$, and ethanol $(100 \mathrm{~mL})$ were placed in a $300 \mathrm{~mL}$ three-necked flask equipped with a condenser. To the solution was added a mixture of formic acid $(5.00 \mathrm{~mL}, 133 \mathrm{mmol})$ and triethylamine $(10.0 \mathrm{~mL}, 72 \mathrm{mmol})$ with stirring. After $10 \mathrm{~min}$, compound 2a $(25.0 \mathrm{~g}, 79.4 \mathrm{mmol})$ in ethanol $(100 \mathrm{~mL})$ was added to the solution. The mixture was stirred at $70{ }^{\circ} \mathrm{C}$ for $4 \mathrm{~h}$. Ethyl acetate $(300 \mathrm{~mL})$ was added to the solution, and the solution was washed with saturated sodium bicarbonate solution and then with water. The organic layer was dried over anhydrous $\mathrm{MgSO}_{4}$. The product was purified by column chromatography (silica gel, eluent: ethyl acetate/hexane $=1: 3$ ) to obtain a white solid; yield $18.9 \mathrm{~g}(87 \%)$. $\mathrm{mp} 134-137^{\circ} \mathrm{C}$. ${ }^{1} \mathrm{H}$ NMR $\left(270 \mathrm{MHz}, \mathrm{CDCl}_{3}\right) \delta 7.78$ (d, 2H, aromatic), 6.73 (d, 2H, aromatic), 5.32 (s, 1H, C=CH-), 1.16$2.11\left(\mathrm{~m}, 16 \mathrm{H}, \mathrm{CH}, \mathrm{CH}_{2}, \mathrm{CH}_{3}\right)$. Anal. Calcd for $\mathrm{C}_{17} \mathrm{H}_{22} \mathrm{O}_{3}$ : C 74.42, H 8.08. Found: C 74.00, H 8.04.

5-Hydroxy-1,3-benzenedicarboxylic acid bis[1-methyl-1-(4-methylcyclohex-3-enyl)ethyl] ester $(\mathbf{3 b})$. The procedure for the synthesis of $\mathbf{3 a}$ was followed using palladium(II) acetate $(20 \mathrm{mg}, 0.089 \mathrm{mmol})$, triphenylphosphine $(40 \mathrm{mg}, 0.15 \mathrm{mmol})$, ethanol $(100 \mathrm{~mL})$, formic acid $(5.00 \mathrm{~mL}, 133 \mathrm{mmol})$, triethylamine $(10.0$ 


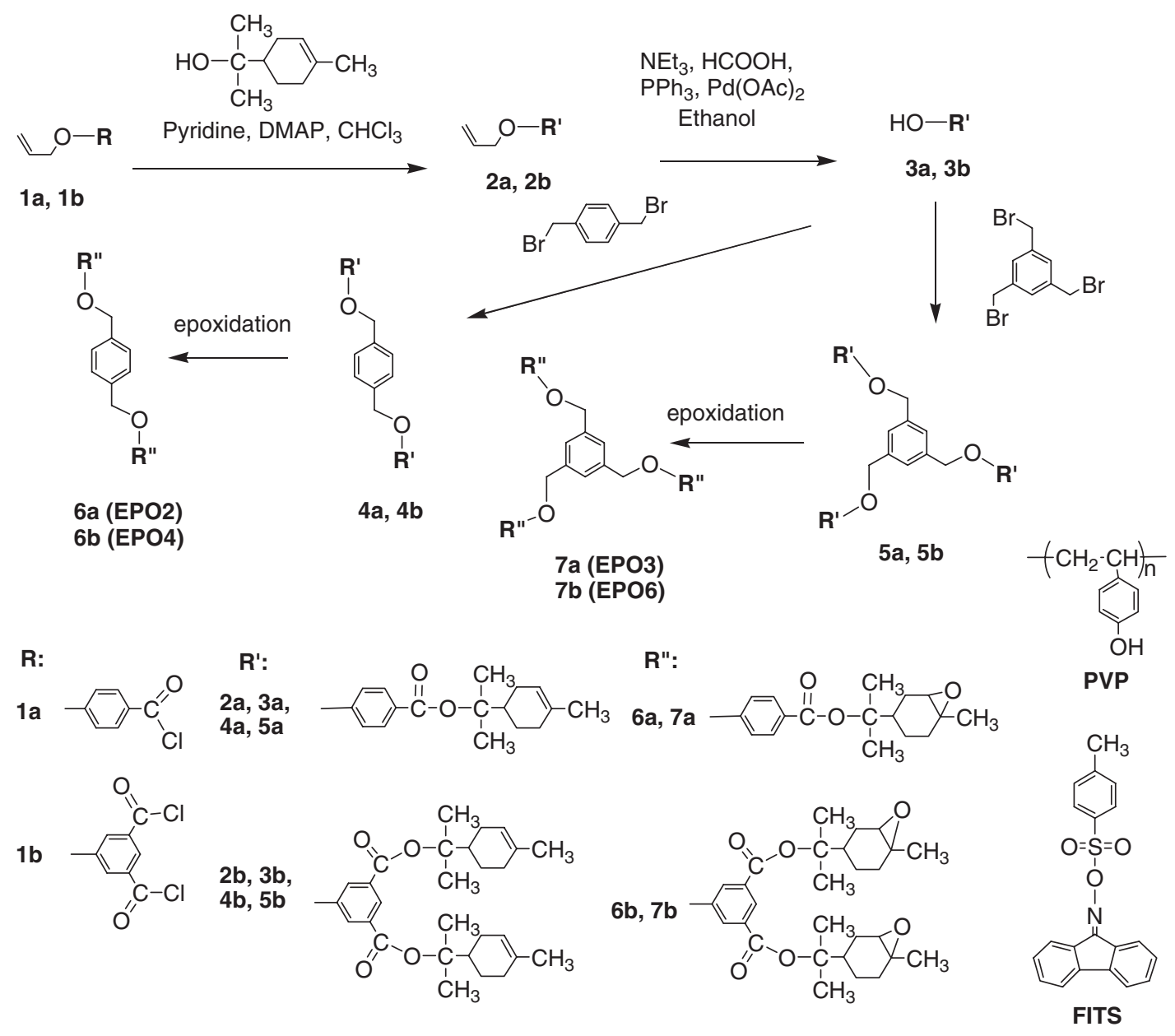

Scheme 1.

$\mathrm{mL}, 72 \mathrm{mmol})$, and an ethanol solution $(100 \mathrm{~mL})$ of compound $2 \mathbf{b}$ ( $10.0 \mathrm{~g}, 20.2 \mathrm{mmol})$. Reaction was carried out at $70^{\circ} \mathrm{C}$ for $21 \mathrm{~h}$. The product was purified by column chromatography (silica gel, eluent: ethyl acetate $/$ hexane $=1: 1)$ to obtain white solid; yield $18.9 \mathrm{~g}(87 \%)$. mp $127-128^{\circ} \mathrm{C} .{ }^{1} \mathrm{H}$ NMR $(270 \mathrm{MHz}$, $\left.\mathrm{CDCl}_{3}\right) \delta 8.03(\mathrm{~s}, 1 \mathrm{H}$, aromatic), $7.68(\mathrm{~d}, 2 \mathrm{H}$, aromatic), $5.28(\mathrm{~s}, 1 \mathrm{H}, \mathrm{C}=\mathrm{CH}-), 1.29-2.11(\mathrm{~m}, 32 \mathrm{H}, \mathrm{CH}$, $\mathrm{CH}_{2}, \mathrm{CH}_{3}$ ). Anal. Calcd for $\mathrm{C}_{28} \mathrm{H}_{38} \mathrm{O}_{5}: \mathrm{C}$ 73.98, $\mathrm{H}$ 8.43. Found: C 73.78, H 8.63.

4,4'-[1,4-Phenylenebis(methyleneoxy)]bisbenzoic acid bis[1-methyl-1-(4-methylcyclohex-3-enyl)eth$y l]$ ester $(4 \mathbf{a})$. To a solution of $\mathbf{3 a}(1.00 \mathrm{~g}, 3.64$ $\mathrm{mmol})$ and 1,4-bis(bromomethyl)benzene $(0.481 \mathrm{~g}$, $1.82 \mathrm{mmol})$ in anhydrous acetone $(10 \mathrm{~mL})$ were added $0.503 \mathrm{~g}(3.64 \mathrm{mmol})$ of potassium carbonate and catalytic amount of 18-crown-6. The reaction mixture was refluxed under $\mathrm{N}_{2}$ for $24 \mathrm{~h}$. After removal of the solvent, the residue was dissolved in ethyl acetate and washed with water twice. The organic layer was separated and evaporated to dryness. The product was purified by column chromatography (silica gel, eluent: ethyl acetate/hexane $=1: 2$ ) to obtain a white solid; yield $1.01 \mathrm{~g}(85 \%)$. mp $162-163{ }^{\circ} \mathrm{C} .{ }^{1} \mathrm{H}$ NMR (270
$\left.\mathrm{MHz}, \mathrm{CDCl}_{3}\right) \delta 7.83(\mathrm{~d}, 4 \mathrm{H}$, aromatic), $7.37(\mathrm{~s}, 4 \mathrm{H}$, aromatic), 6.87 (d, $4 \mathrm{H}$, aromatic), $5.32(\mathrm{~s}, 2 \mathrm{H}, \mathrm{C}=$ $\mathrm{CH}-), 5.05\left(\mathrm{~s}, 4 \mathrm{H},-\mathrm{CH}_{2} \mathrm{O}\right), 1.29-2.11(\mathrm{~m}, 32 \mathrm{H}, \mathrm{CH}$, $\mathrm{CH}_{2}, \mathrm{CH}_{3}$ ). Anal. Calcd for $\mathrm{C}_{42} \mathrm{H}_{50} \mathrm{O}_{6}: \mathrm{C} 77.51, \mathrm{H}$ 7.74. Found: C 77.22, H 7.93.

4,4', $4^{\prime \prime}-[1,3,5$-Benzenetriyltris(methyleneoxy)]trisbenzoic acid tris[1-methyl-1-(4-methylcyclohex-3enyl)ethyl] ester $(\mathbf{5 a})$. The procedure for the synthesis of $\mathbf{4 a}$ was followed using $1.00 \mathrm{~g}(3.64 \mathrm{mmol})$ of $\mathbf{3 a}$, $0.433 \mathrm{~g}(1.21 \mathrm{mmol})$ of 1,3,5-tris(bromomethyl)benzene, and $0.503 \mathrm{~g}(3.64 \mathrm{mmol})$ of $\mathrm{K}_{2} \mathrm{CO}_{3}$. The product was purified by column chromatography (silica gel, eluent: ethyl acetate/hexane $=1: 2$ ) to obtain a white solid; yield $1.08 \mathrm{~g}$ (95\%). mp $45-48{ }^{\circ} \mathrm{C}$. ${ }^{1} \mathrm{H}$ NMR $\left(270 \mathrm{MHz}, \mathrm{CDCl}_{3}\right) \delta 7.83(\mathrm{~d}, 6 \mathrm{H}$, aromatic), $7.40(\mathrm{~s}$, $3 \mathrm{H}$, aromatic), $6.88(\mathrm{~d}, 6 \mathrm{H}$, aromatic), $5.32(\mathrm{~s}, 3 \mathrm{H}$, $\mathrm{C}=\mathrm{CH}-), 5.06\left(\mathrm{~s}, 6 \mathrm{H},-\mathrm{CH}_{2} \mathrm{O}\right), 1.18-2.09(\mathrm{~m}, 48 \mathrm{H}$, $\mathrm{CH}, \mathrm{CH}_{2}, \mathrm{CH}_{3}$ ). Anal. Calcd for $\mathrm{C}_{60} \mathrm{H}_{72} \mathrm{O}_{9}$ : C 76.89, H 7.74. Found: C 76.59, H 7.69.

5,5'-[1,4-Phenylenebis(methyleneoxy)]bis-1,3-benzenedicarboxylic acid tetrakis[1-methyl-1-(4-methylcyclohex-3-enyl)ethyl] ester $(\mathbf{4 b})$. The above procedure was followed using $0.400 \mathrm{~g}(1.57 \mathrm{mmol})$ of $\mathbf{3 b}$, $0.116 \mathrm{~g}(0.785 \mathrm{mmol})$ of 1,4-bis(bromomethyl)ben- 
zene, and $0.182 \mathrm{~g}(2.36 \mathrm{mmol})$ of $\mathrm{K}_{2} \mathrm{CO}_{3}$. The product was purified by column chromatography (silica gel, eluent: ethyl acetate/chloroform $=1: 5$ ) to obtain a white glassy solid; yield $0.430 \mathrm{~g}$ (97\%). ${ }^{1} \mathrm{H}$ NMR $\left(270 \mathrm{MHz}, \mathrm{CDCl}_{3}\right) \delta 8.13$ (s, 2H, aromatic), $7.71(\mathrm{~s}$, $4 \mathrm{H}$, aromatic), $7.45(\mathrm{~d}, 4 \mathrm{H}$, aromatic), $5.36(\mathrm{~s}, 4 \mathrm{H}, \mathrm{C}=$ $\mathrm{CH}-), 5.12\left(\mathrm{~s}, 4 \mathrm{H},-\mathrm{CH}_{2} \mathrm{O}\right), 1.29-2.11(\mathrm{~m}, 64 \mathrm{H}, \mathrm{CH}$, $\mathrm{CH}_{2}, \mathrm{CH}_{3}$ ). Anal. Calcd for $\mathrm{C}_{64} \mathrm{H}_{82} \mathrm{O}_{10}: \mathrm{C} 76.01, \mathrm{H}$ 8.17. Found: C 75.59, H 8.30.

$5,5^{\prime}, 5^{\prime \prime}-[1,3,5-B e n z e n e t r i y l t r i s(m e t h y l e n e o x y)] t r i s-$ 1,3-benzenedicarboxylic acid hexakis[1-methyl-1-(4methylcyclohex-3-enyl)ethyl] ester $(5 \boldsymbol{b})$. The above procedure was followed using $3.50 \mathrm{~g}(13.8 \mathrm{mmol})$ of 3b, $0.935 \mathrm{~g}$ ( $2.62 \mathrm{mmol})$ of 1,3,5-tris(bromomethyl)benzene, and $1.09 \mathrm{~g}(7.86 \mathrm{mmol})$ of $\mathrm{K}_{2} \mathrm{CO}_{3}$. The product was purified by column chromatography (silica gel, eluent: ethyl acetate $/$ hexane $=1: 2$ ) to obtain a brown viscous liquid; yield $3.81 \mathrm{~g}$ (98\%). ${ }^{1} \mathrm{H}$ NMR $\left(270 \mathrm{MHz}, \mathrm{CDCl}_{3}\right) \delta 8.10(\mathrm{~s}, 3 \mathrm{H}$, aromatic), $7.68(\mathrm{~s}$, $6 \mathrm{H}$, aromatic), 7.45 (s, 3H, aromatic), $5.30(\mathrm{~s}, 6 \mathrm{H}, \mathrm{C}=$ $\mathrm{CH}-$ ), 5.02 (s, 6H, $\left.-\mathrm{CH}_{2} \mathrm{O}\right), 1.29-2.11(\mathrm{~m}, 96 \mathrm{H}, \mathrm{CH}$, $\mathrm{CH}_{2}, \mathrm{CH}_{3}$ ). Anal. Calcd for $\mathrm{C}_{93} \mathrm{H}_{120} \mathrm{O}_{15}: \mathrm{C} 75.58, \mathrm{H}$ 8.18. Found: C 75.46, H 8.31.

General Procedure for Epoxidation. Into a threenecked round-bottom flask fitted with an efficient magnetic stirrer, a Claisen adapter, two addition funnels, and a $\mathrm{pH}$ meter electrode were placed the precursor ester, chloroform, acetone, phosphate buffer $(\mathrm{pH}=7.4)$, and catalytic amount of 18-crown-6. The flask was cooled to $0-5{ }^{\circ} \mathrm{C}$ using an ice-water bath. A solution of OXONE $\left(2 \mathrm{KHSO}_{5} \cdot \mathrm{KHSO}_{4} \cdot \mathrm{K}_{2} \mathrm{SO}_{4}\right)$ in water was added dropwise over the course of $1 \mathrm{~h}$. At the same time, $1 \mathrm{~N} \mathrm{KOH}$ was added dropwise to keep the reaction mixture at $\mathrm{pH} 7.1-7.5$. After addition of OXONE, the reaction mixture was stirred at $0-5^{\circ} \mathrm{C}$ for $9 \mathrm{~h}$. The resulting mixture was filtered and extracted with chloroform three times, and the combined organic layer was washed with water twice, dried over anhydrous $\mathrm{MgSO}_{4}$, and evaporated to dryness. The pure product was purified by silica column chromatography.

4,4'-[1,4-Phenylenebis (methyleneoxy)]bisbenzoic acid bis[1-methyl-1-(6-methyl-7-oxabicyclo[4,1,0]hept-3-yl)ethyl] ester (6a, EPO2). The above procedure was followed using $0.90 \mathrm{~g}(1.38 \mathrm{mmol})$ of $\mathbf{4 a}$, $10 \mathrm{~mL}$ of chloroform, $5.0 \mathrm{~mL}$ of acetone, a solution of OXONE $(2.81 \mathrm{~g}, 4.58 \mathrm{mmol})$ in water $(14 \mathrm{~mL})$, and $14 \mathrm{~mL}$ of phosphate buffer. The product was purified by column chromatography (silica gel, eluent: ethyl acetate/chloroform $=1: 8$ ) to obtain a white solid; yield $0.81 \mathrm{~g}(86 \%) . \mathrm{mp} 165-167{ }^{\circ} \mathrm{C} .{ }^{1} \mathrm{H}$ NMR $\left(270 \mathrm{MHz}, \mathrm{CDCl}_{3}\right) \delta 7.81$ (d, $4 \mathrm{H}$, aromatic), 7.37 (s, $4 \mathrm{H}$, aromatic), 6.87 (d, $4 \mathrm{H}$, aromatic), $5.05(\mathrm{~s}, 4 \mathrm{H}$, $-\mathrm{CH}_{2} \mathrm{O}$ ), 2.91 (d, 2H, epoxy $\left.\mathrm{HCOC}\right), 1.29-2.11$ (m, $32 \mathrm{H}, \mathrm{CH}, \mathrm{CH}_{2}, \mathrm{CH}_{3}$ ). Anal. Calcd for $\mathrm{C}_{42} \mathrm{H}_{50} \mathrm{O}_{8}: \mathrm{C}$ 73.88, H 7.38. Found: C 73.73, H 7.67.
4,4', 4" - [1,3,5-Benzenetriyltris(methyleneoxy)]trisbenzoic acid tris[1-methyl-1-(6-methyl-7-oxabicyclo[4,1,0] hept-3-yl)ethyl] ester (7a, EPO3). The above procedure was followed using $0.98 \mathrm{~g}(1.05 \mathrm{mmol})$ of 5a, $10 \mathrm{~mL}$ of chloroform, $6.0 \mathrm{~mL}$ of acetone, a solution of OXONE $(3.38 \mathrm{~g}, 5.51 \mathrm{mmol})$ in water $(20$ $\mathrm{mL}$ ), and $18 \mathrm{~mL}$ of phosphate buffer. The product was purified by column chromatography (silica gel, eluent: ethyl acetate/chloroform $=1: 8$ ) to obtain a white glassy solid; yield $1.03 \mathrm{~g}$ (99\%). ${ }^{1} \mathrm{H}$ NMR $\left(270 \mathrm{MHz}, \mathrm{CDCl}_{3}\right) \delta 7.83(\mathrm{~d}, 6 \mathrm{H}$, aromatic), 7.40 (s, $3 \mathrm{H}$, aromatic), $6.88(\mathrm{~d}, 6 \mathrm{H}$, aromatic), $5.07(\mathrm{~s}, 6 \mathrm{H}$, $-\mathrm{CH}_{2} \mathrm{O}$ ), 2.91 (d, 3H, epoxy $\mathrm{HCOC}$ ), 1.05-2.23 (m, $48 \mathrm{H}, \mathrm{CH}, \mathrm{CH}_{2}, \mathrm{CH}_{3}$ ). Anal. Calcd for $\mathrm{C}_{60} \mathrm{H}_{72} \mathrm{O}_{12}$ : C 73.15, H 7.37. Found: C 73.02, H 7.44.

5,5'-[1,4-Phenylenebis(methyleneoxy)]bis-1,3-benzenedicarboxylic acid tetrakis[1-methyl-1-(6-methyl7-oxabicyclo[4,1,0] hept-3-yl)ethyl] ester (6b, EPO4). The above procedure was followed using $1.10 \mathrm{~g}$ $(1.09 \mathrm{mmol})$ of $\mathbf{4 b}, 10 \mathrm{~mL}$ of chloroform, $8.0 \mathrm{~mL}$ of acetone, a solution of OXONE $(4.40 \mathrm{~g}, 7.17 \mathrm{mmol})$ in water $(30 \mathrm{~mL})$, and $25 \mathrm{~mL}$ of phosphate buffer. The product was purified by column chromatography (silica gel, eluent: ethyl acetate/chloroform $=1: 4$ ) to obtain a white glassy solid; yield $0.85 \mathrm{~g}(73 \%)$. ${ }^{1} \mathrm{H} \mathrm{NMR}\left(270 \mathrm{MHz}, \mathrm{CDCl}_{3}\right) \delta 8.09$ (s, 2H, aromatic), $7.69(\mathrm{~s}, 4 \mathrm{H}$, aromatic), 7.47 (s, $4 \mathrm{H}$, aromatic), 5.12 (s, $4 \mathrm{H},-\mathrm{CH}_{2} \mathrm{O}$ ), 2.91 (d, 4H, epoxy $\left.\mathrm{HCOC}\right), 1.29-2.11$ (m, $64 \mathrm{H}, \mathrm{CH}, \mathrm{CH}_{2}, \mathrm{CH}_{3}$ ). Anal. Calcd for $\mathrm{C}_{64} \mathrm{H}_{82} \mathrm{O}_{14}$ : C 71.48, H 7.69. Found: C 71.06, H 7.83.

$5,5^{\prime}, 5^{\prime \prime}-[1,3,5-B e n z e n e t r i y l t r i s($ methyleneoxy) $]$ tris1,3-benzenedicarboxylic acid hexakis[1-methyl-1-(6methyl-7-oxabicyclo[4,1,0] hept-3-yl)ethyl] ester (7b, EPO6). The above procedure was followed using $2.0 \mathrm{~g}(1.09 \mathrm{mmol})$ of $\mathbf{5 b}, 15 \mathrm{~mL}$ of chloroform, $15 \mathrm{~mL}$ of acetone, a solution of OXONE (8.69 g, $14.2 \mathrm{mmol})$ in water $(30 \mathrm{~mL})$, and $45 \mathrm{~mL}$ of phosphate buffer. The product was purified by column chromatography (silica gel, eluent: ethyl acetate/chloroform $=1: 1$ ) to obtain a white glassy solid; yield $1.81 \mathrm{~g}(85 \%) .{ }^{1} \mathrm{H}$ NMR $\left(270 \mathrm{MHz}, \mathrm{CDCl}_{3}\right) \delta 8.07$ (s, 3H, aromatic), $7.66(\mathrm{~s}$, $6 \mathrm{H}$, aromatic), $7.48(\mathrm{~s}, 3 \mathrm{H}$, aromatic), $5.10(\mathrm{~s}, 6 \mathrm{H}$, $-\mathrm{CH}_{2} \mathrm{O}$ ), 2.91 (d, 6H, epoxy HCOC), 1.29-2.11 (m, $\left.96 \mathrm{H}, \mathrm{CH}, \mathrm{CH}_{2}, \mathrm{CH}_{3}\right)$. Anal. Calcd for $\mathrm{C}_{93} \mathrm{H}_{120} \mathrm{O}_{21}$ : C 70.97, H 7.68. Found: C 70.58, H 7.86.

\section{Photocrosslinking and Thermal Decrosslinking}

Sample films were prepared on silicon wafer by spin-casting from solutions of cyclohexanone containing PVP, crosslinker (EPO2, EPO3, EPO4, or EPO6), and FITS. The sample films were dried on a hot plate at $90^{\circ} \mathrm{C}$ for $1 \mathrm{~min}$. The thickness of films was about $0.5 \mu \mathrm{m}$ except for the sample films for the FT-IR measurements $(1.2 \mu \mathrm{m})$. Irradiation was performed at $254 \mathrm{~nm}$ in air using a low-pressure mercury lamp 
(Ushio ULO-6DQ, 6 W) without a filter. The intensity of the light was measured with an Orc Light Measure UV-M02. Insoluble fraction was determined by comparing the film thickness before and after dissolution in tetrahydrofuran (THF). Thickness of films was measured by interferometry (Nanometrics Nanospec M3000).

\section{Measurements}

${ }^{1} \mathrm{H}$ NMR spectra were observed at $270 \mathrm{MHz}$ using a JEOL GX-270 spectrometer. UV-vis spectra were taken on a Shimadzu UV-2400 PC. FT-IR measurements were carried out using a JASCO IR-410. In situ FT-IR measurements were carried out using a Litho Tech Japan PAGA-100. Thermal decomposition behavior was investigated with a Shimadzu TGA 50 thermogravimetric analyzer (TGA).

\section{RESULTS AND DISCUSSION}

\section{Synthesis and Thermal Properties of Crosslinkers}

On the basis of the concept shown in Figure 1, multifunctional crosslinkers which have both epoxy moieties and tertiary ester linkages in a molecule were prepared (see Scheme 1). A convergent approach was adopted to increase functionality of epoxy and tertiary ester units. Phenol derivatives $\mathbf{3 a}$ and $\mathbf{3 b}$ which have both epoxy and tertiary ester units were obtained by protection of phenol unit with allyl unit ${ }^{21,23}$ and palladium-catalyzed deprotection. ${ }^{21,23}$ The reaction of the phenol derivatives and bis- or tris(bromomethyl)benzene proceeded in good yields (85-98\%) under mild conditions, i.e., relatively low temperatures and without strong acids or bases. The mild reaction conditions are essentially important for the synthesis of compounds having acid- or base-labile units. Moreover, the sequential operation of phenol derivatives by deprotection of allyloxy unit and Williamson ether reaction is a promising way to synthesize multifunctional dendritic epoxy crosslinkers.

The conversion of olefinic double bond into an epoxy moiety proceeded in good yields (73-99\%). The epoxy units work as a photoinduced crosslinking site if these compounds are used in combination with photoacid generators. Tertiary esters are known to decompose to carboxylic acid and alkene by thermal treatment at temperatures lower than those for primary and secondary esters. Furthermore, the temperature for the tertiary ester cleavage is lowered in the presence of strong acids. ${ }^{24}$

The thermal decomposition behavior of these crosslinkers was studied using TGA. Figure 2 shows the TGA curves of EPO2, EPO3, EPO4, and EPO6. When the crosslinkers were heated under nitrogen at the heating rate $\left(10^{\circ} \mathrm{C} / \mathrm{min}\right), \mathrm{EPO} 2, \mathrm{EPO} 3, \mathrm{EPO} 4$, and

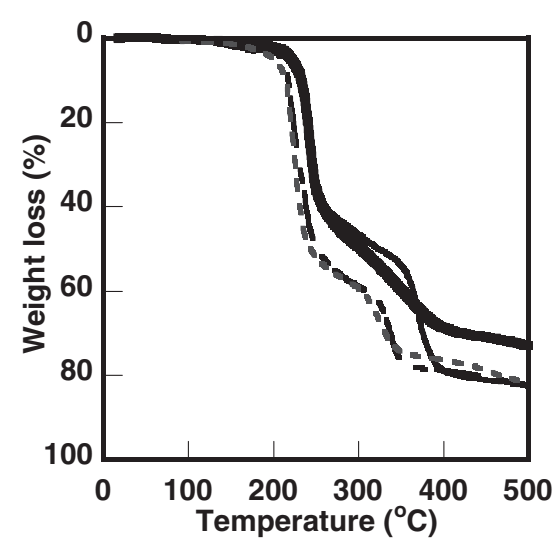

Figure 2. TGA curves of crosslinkers under nitrogen. Heating rate: $10^{\circ} \mathrm{C} / \mathrm{min}$. Solid line: EPO2. Bold line: EPO3. Dot-dash line: EPO6. Broken line: EPO4.

EPO6 started to lose their weights at 232, 229, 212, and $214{ }^{\circ} \mathrm{C}$, respectively. Thermal decomposition temperatures of EPO4 and EPO6 were about $20^{\circ} \mathrm{C}$ lower than those for EPO2 and EPO3. Bulky terpene groups connected with a benzene ring at meta position slightly lowered the thermal stability of EPO4 and EPO6. The weight loss of EPO2 and EPO3 was 42 and $43 \%$ at $270{ }^{\circ} \mathrm{C}$, respectively. The values agreed with the calculated values for formation of corresponding carboxylic acid (45 and 46\%, respectively), suggesting the complete cleavage of tertiary ester linkages in EPO2 and EPO3. In the case of EPO4 and EPO6, the weight loss at $250^{\circ} \mathrm{C}$ was 50 and $52 \%$, respectively. The values were almost consistent with the theoretical values (57 and 58\%, respectively) for the formation of corresponding carboxylic acid. A little difference between theoretical and observed values for the case of EPO4 and EPO6 was observed. However, the difference (6-7\%) was relatively small compared to the case of benzene-1,3,5-tricarboxylic acid tris[1-methyl-1-(6-methyl-7-oxabicyclo[4,1,0]hept-3-yl)ethyl] ester reported previously $(12 \%) .{ }^{18}$

\section{Photocrosslinking and Decrosslinking Properties}

Figure 3 shows the insolubilization profiles of $\mathrm{PVP} /$ crosslinker blended films containing $5 \mathrm{wt} \%$ of FITS on irradiation with a dose of $60 \mathrm{~mJ} / \mathrm{cm}^{2}$ and followed by baking at above $80^{\circ} \mathrm{C}$ for $10 \mathrm{~min}$. The amount of epoxy unit in all blended films was adjusted to $40 \mathrm{~mol} \%$ for phenolic $-\mathrm{OH}$ units in PVP. FITS was used as a photoacid generator which can generate $p$ toluenesulfonic acid on irradiation with UV light. ${ }^{25,26}$ Insoluble fraction was determined by comparing the film thickness before and after dipping the films in THF. THF was a good solvent for not only PVP but also FITS, crosslinkers, and the compounds generated by thermolysis of the crosslinkers.

When the blended films were irradiated with $60 \mathrm{~mJ} /$ 


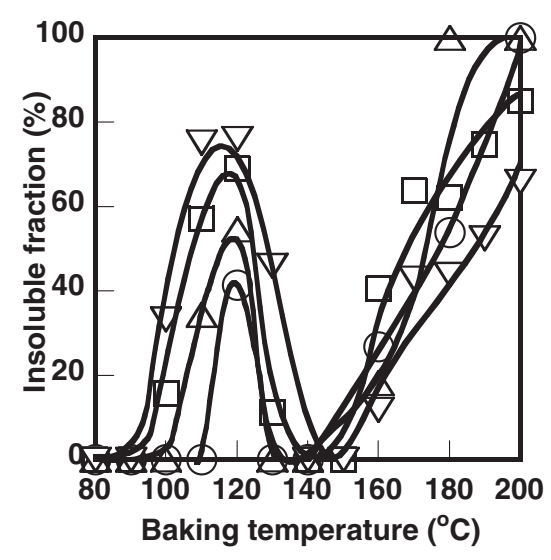

Figure 3. Effect of baking temperature on insolubilization of the PVP/crosslinker blended film containing $5 \mathrm{wt} \%$ of FITS. Film thickness: $0.5 \mu \mathrm{m}$. Irradiation dose: $60 \mathrm{~mJ} / \mathrm{cm}^{2}$. Baking time: 10 min. Dissolution: in THF for $10 \mathrm{~min}$. Crosslinker: $(\mathrm{O}) \mathrm{EPO}$, $(\triangle)$ EPO3, $(\square)$ EPO4, $(\nabla)$ EPO6.

$\mathrm{cm}^{2}$ and baked below $80^{\circ} \mathrm{C}$ for $10 \mathrm{~min}$, insolubilization was not observed for all films. The insolubilization degree of the blended films increased, reached to a maximum value, decreased and increased again with a rise of baking temperature. The maximum insoluble fraction was observed for all films when baked at $120^{\circ} \mathrm{C}$, suggesting that the reaction mechanism and reaction kinetics for the insolubilization and dissolution of the $\mathrm{PVP} /$ crosslinker systems resemble each other. Insolubilization degree of $\mathrm{PVP} /$ crosslinker blended films increased with the number of epoxy unit of a crosslinker molecule when baked at between 90 and $130^{\circ} \mathrm{C}$ for $10 \mathrm{~min}$ after irradiation. The insolubilization was due to the photoinduced-acid catalyzed crosslinking reaction of epoxy moiety of crosslinker and phenolic -OH units in PVP. It was confirmed by FT-IR measurements that decomposition of tertiary ester linkages of the crosslinkers did not occur by PEB treatment at 100 and $110^{\circ} \mathrm{C}$ for $10 \mathrm{~min}$. No insolubilization of the unirradiated films was observed by baking up to $180^{\circ} \mathrm{C}$.

When the blended films were baked at $140{ }^{\circ} \mathrm{C}$ for $10 \mathrm{~min}$ after irradiation, the films completely dissolved in THF. The films also dissolved in methanol and $2.38 \mathrm{wt} \%$ tetramethylammonium hydroxide solution. Cleavage of tertiary ester linkages in the crosslinker occurred. In the case of PVP/EPO6 blended system, at least $83 \%$ cleave of tertiary ester linkages in EPO6 was necessary for dissolution. This was supported by the finding from TGA analysis.

The re-insolubilization for the blended films on baking at above $160^{\circ} \mathrm{C}$ for $10 \mathrm{~min}$ was due to the reaction of the $-\mathrm{OH}$ groups in PVP and corresponding carboxylic acid generated from the thermolysis of crosslinkers.

The dependence of the insoluble fraction of

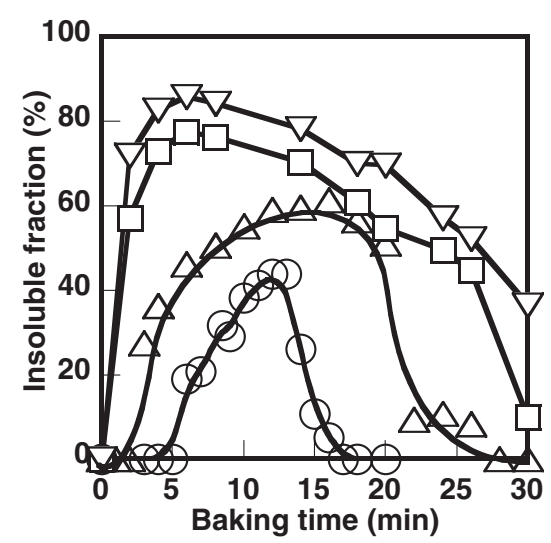

Figure 4. Effect of baking time on insolubilization of the $\mathrm{PVP} /$ crosslinker blended film containing $5 \mathrm{wt} \%$ of FITS. Film thickness: $0.5 \mu \mathrm{m}$. Irradiation dose: $60 \mathrm{~mJ} / \mathrm{cm}^{2}$. Baking temperature: $120^{\circ} \mathrm{C}$. Dissolution: in THF for $10 \mathrm{~min}$. Crosslinker: $(\bigcirc)$ EPO2, $(\triangle)$ EPO3, $(\square)$ EPO4, $(\nabla)$ EPO6.

the blended films on baking time was investigated (Figure 4). When the PVP/EPO2 blended film was baked at $120^{\circ} \mathrm{C}$ for $13 \mathrm{~min}$, the insoluble fraction of the films reached a maximum value (43\%), and decreased to zero after bake treatment for $17 \mathrm{~min}$. In the case of the PVP/EPO6 blended system, the insoluble fraction became $86 \%$ on baking for $6 \mathrm{~min}$, and decreased by prolonged baking. These results strongly suggest that crosslinking and decrosslinking reaction occurs simultaneously. The crosslinkers with higher functionality have an advantage for the network formation. The drastic increase of insoluble fractions was observed for PVP/EPO6 blended system. However, higher functionality is unfavorable for the dissolution of crosslinked films because higher conversion for the decomposition of network is necessary.

The dependence of the insoluble fraction of the blended films on irradiation dose was investigated (Figure 5). Sensitivity of PVP/EPO6 blended films was less than $1 \mathrm{~mJ} / \mathrm{cm}^{2}$ when the blended films were baked at $120^{\circ} \mathrm{C}$ for $10 \mathrm{~min}$ after irradiation. The sensitivity for PVP/EPO6 was 100 times higher than that for PVP/EPO2 system. The high functionality of the crosslinkers drastically enhanced the sensitivity of the system.

To investigate the reaction mechanism, in situ FTIR measurements of PVP/EPO6 blended system were carried out (Figure 6). The peaks due to ester carbonyl $\left(1715 \mathrm{~cm}^{-1}\right)$ and ester $\mathrm{C}-\mathrm{O}$ groups $\left(1260 \mathrm{~cm}^{-1}\right)$ decreased with the increase of baking time. On the other hand, the peak due to ester carbonyl $\left(1715 \mathrm{~cm}^{-1}\right)$ showed slight sift to $1711 \mathrm{~cm}^{-1}$, which may be due to the formation of carboxylic acid groups. The two peaks $\left(1711,1715 \mathrm{~cm}^{-1}\right)$ were not separated. Using the peak at $1260 \mathrm{~cm}^{-1}$, thermal decomposition behavior of the tertiary ester linkages in crosslinker was 


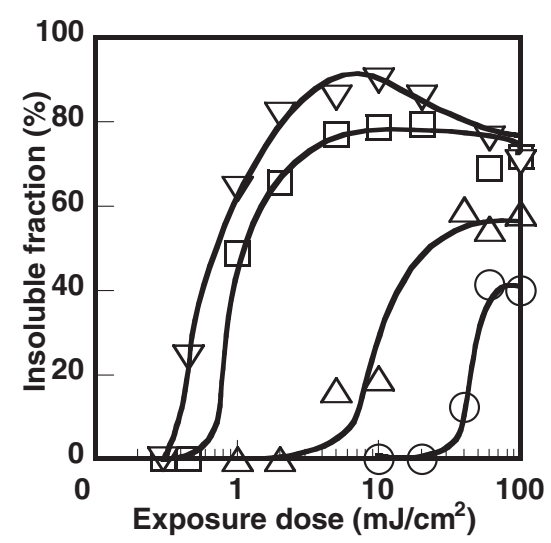

Figure 5. Effect of irradiation dose on insolubilization of the $\mathrm{PVP} /$ crosslinker blended film containing $5 \mathrm{wt} \%$ of FITS. Film thickness: $0.5 \mu \mathrm{m}$. Baking condition: $120^{\circ} \mathrm{C}$ for $10 \mathrm{~min}$. Dissolution: in THF for $10 \mathrm{~min}$. Crosslinker: $(\bigcirc) \mathrm{EPO} 2,(\triangle) \mathrm{EPO}$, $(\square)$ EPO4, $(\nabla)$ EPO6.

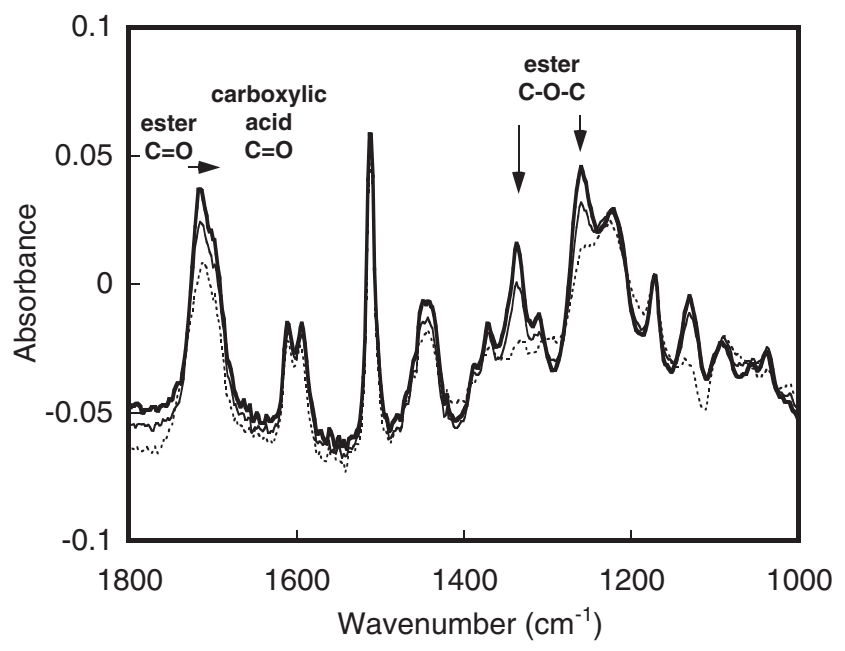

Figure 6. Effect of bake treatment at $140{ }^{\circ} \mathrm{C}$ on FT-IR spectra of PVP/EPO6 blended film containing $5 \mathrm{wt} \%$ of FITS. Film $(1.2 \mu \mathrm{m})$ was irradiated with a dose of $60 \mathrm{~mJ} / \mathrm{cm}^{2}$ at $254 \mathrm{~nm}$. Bold line: before baking, Solid line: after baking for $2 \mathrm{~min}$, Dotted line: after baking for $10 \mathrm{~min}$.

studied. Figure 7 shows the decomposition rate of ester units of the irradiated PVP/EPO6 blended films on baking at $140{ }^{\circ} \mathrm{C}$. The baking time for $50 \%$ decomposition of ester groups was $c a .2 \mathrm{~min}$. The complete dissolution of the films in THF needed at least 8 min baking at $140^{\circ} \mathrm{C}$. Thus, almost complete decomposition of the ester units was necessary for the dissolution of the crosslinked films. It was difficult to study the crosslinking process of epoxy units using FT-IR measurements.

A reaction mechanism of PVP/EPO6 blended system is shown in Scheme 2. On irradiation, FITS was photolyzed to generate $p$-toluenesulfonic acid. The acid catalyzed the crosslinking reaction of $-\mathrm{OH}$ moiety in PVP and epoxy moiety in the crosslinker. The baking treatment of irradiated films at relatively lower

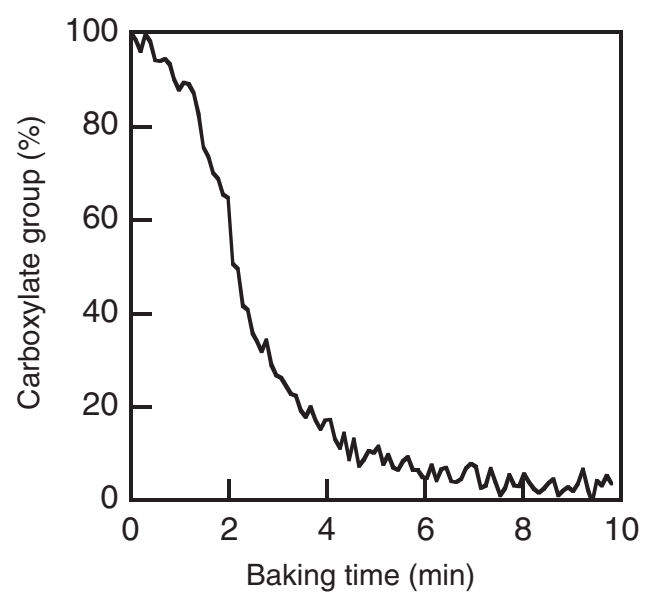

Figure 7. In situ observation of carboxylate group (1260 $\mathrm{cm}^{-1}$ ) of the irradiated PVP/EPO6 blended film on baking at $140{ }^{\circ} \mathrm{C}$. Irradiation dose: $60 \mathrm{~mJ} / \mathrm{cm}^{2}$.

temperatures enhanced the crosslinking reactions. Acid-catalyzed cleavage of tertiary ester linkages in the crosslinker occurred by baking treatment for a long time. Complete degradation of ester linkages in PVP/crosslinker blended films occurred by proper baking conditions. However, if baked at above $160^{\circ} \mathrm{C}$, the insolubilization was observed again. The re-increase in the insoluble fraction was caused by the formation of esters from phenolic $-\mathrm{OH}$ groups in $\mathrm{PVP}$ and $-\mathrm{COOH}$ units in carboxylic acid generated by the thermolysis of the crosslinkers.

\section{CONCLUSIONS}

Highly functionalized crosslinkers having both tertiary ester unit and epoxy unit were synthesized. PVP/ crosslinker blended films containing a photoacid generator became insoluble in solvents on UV irradiation and baking at relatively low temperatures $\left(<100^{\circ} \mathrm{C}\right)$. With a rise in baking temperature, the insoluble fraction of the irradiated films increased, passed through a maximum value, decreased, and increased again at elevated temperatures. The initial insolubilization was due to the photoinduced acid-catalyzed reaction between epoxy units and phenolic $-\mathrm{OH}$ groups. The hexa-functionalized crosslinker was the most effective crosslinker. Dissolution of the crosslinked film on baking was due to the thermal cleavage of tertiary ester units in the crosslinker molecules.

Acknowledgment. This work has been supported in part by a 21st Century COE Program 24403 E-1 and a Grant-in-Aid for Young Scientists (B) No. 16750166 from the Ministry of Education, Culture, Sports, Science and Technology. We are also grateful to Tokyo Ohka Foundation for the Promotion of Science and Technology. 


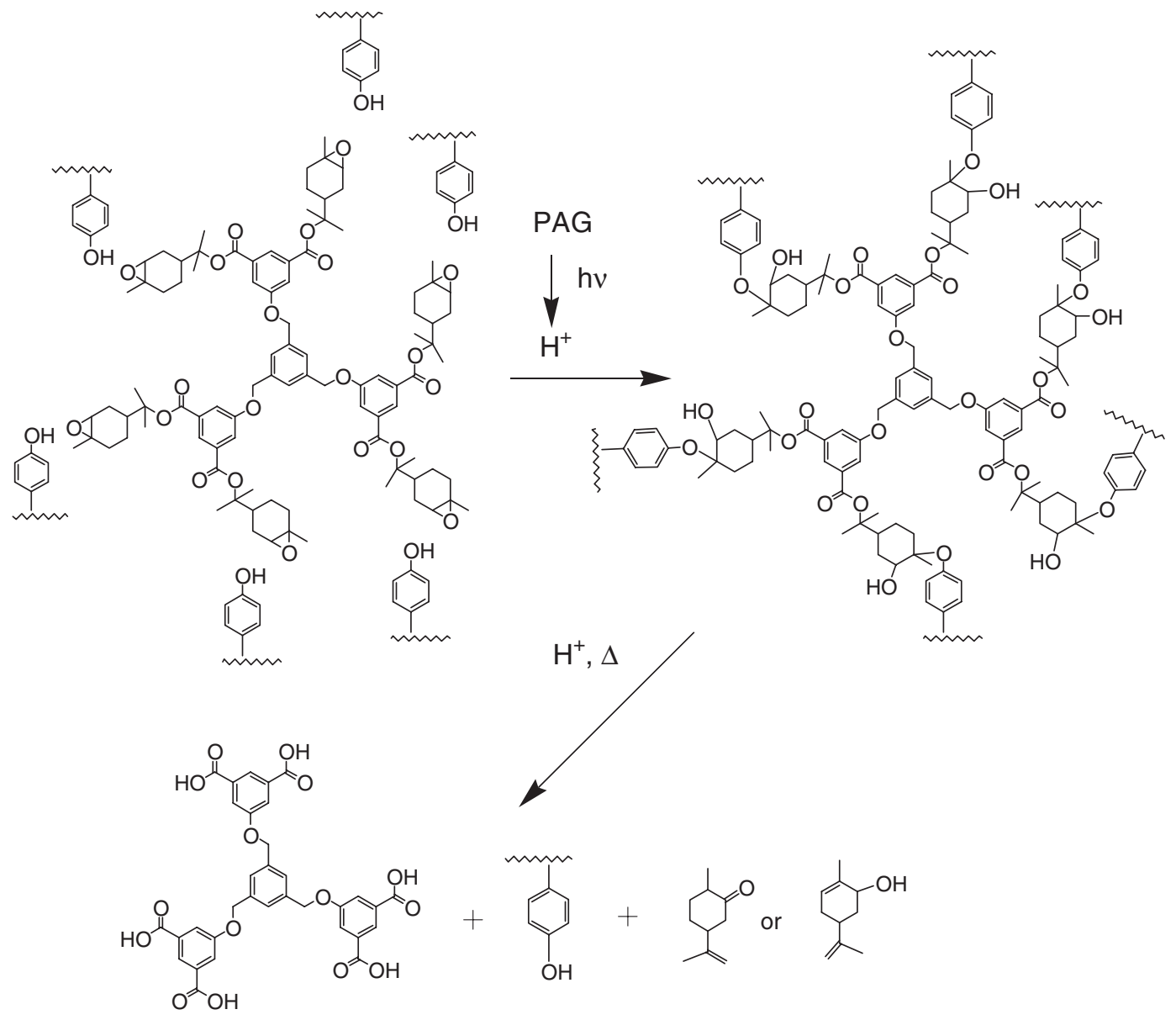

Scheme 2.

\section{REFERENCES}

1. G. C. Tesero and V. Sastri, J. Appl. Polym. Sci., 39, 1425 (1990).

2. V. Sastri and G. C. Tesero, J. Appl. Polym. Sci., 39, 1439 (1990).

3. S. L. Buchwalter and L. L. Kosber, J. Polym. Sci., Part A: Polym. Chem., 34, 249 (1996).

4. S. Yang, J.-S. Chen, H. Korner, T. Breiner, and C. K. Ober, Chem. Mater., 10, 1475 (1998).

5. J.-S. Chen, C. K. Ober, and M. D. Poliks, Polymer, 43, 131 (2002).

6. K. Ogino, J.-S. Chen, and C. K. Ober, Chem. Mater., 10, 3833 (1998).

7. L. Wang, H. Li, and C. P. Wong, J. Polym. Sci., Part A: Polym. Chem., 38, 3771 (2000).

8. L. Wang and C. P. Wong, J. Polym. Sci., Part A: Polym. Chem., 37, 2991 (1999).

9. J. Malik and S. J. Clarson, Polym. Degrad. Stab., 76, 241 (2002).

10. J. Malik and S. J. Clarson, Polymer, 43, 2561 (2002).

11. Z. G. Wang, M. R. Xie, Y. F. Zhao, Y. Z. Yu, and S. B. Fang, Polymer, 44, 923 (2003).

12. M. Shirai, S. Morishita, H. Okamura, and M. Tsunooka, Chem. Mater., 14, 334 (2002).

13. H. Okamura, S. Toda, M. Tsunooka, and M. Shirai, J.
Polym. Sci., Part A: Polym. Chem., 40, 3055 (2002).

14. M. Shirai, A. Kawaue, H. Okamura, and M. Tsunooka, Chem. Lett., 31, 940 (2002).

15. M. Shirai, A. Kawaue, H. Okamura, and M. Tsunooka, Chem. Mater., 15, 4075 (2003).

16. Y.-D. Shin, A. Kawaue, H. Okamura, and M. Shirai, Polym. Degrad. Stab., 86, 153 (2004).

17. Y.-D. Shin, A. Kawaue, H. Okamura, and M. Shirai, React. Funct. Polym., 61, 293 (2004).

18. H. Okamura, K. Shin, M. Tsunooka, and M. Shirai, J. Polym. Sci., Part A: Polym. Chem., 42, 3685 (2004).

19. M. Shirai, H. Kinoshita, and M. Tsunooka, Eur. Polym. J., 28, 379 (1992).

20. W. Offermann and F. Vogtle, Synthesis, 4, 273 (1977).

21. M. McWatt and G. J. Boons, Eur. J. Org. Chem., 2535 (2001).

22. N. Nemoto, F. Miyata, and Y. Nagase, Macromolecules, 29, 2365 (1996).

23. C.-A. Fustin, C. Bailly, G. J. Clarkson, P. De Groote, T. H. Galow, D. A. Leigh, D. Robertson, A. M. Z. Slawin, and J. K. Y. Wong, J. Am. Chem. Soc., 125, 2200 (2003).

24. H. Ito and M. Ueda, Macromolecules, 21, 1475 (1998).

25. M. Shirai and M. Tsunooka, Bull. Chem. Soc. Jpn., 71, 2483 (1998).

26. J. Lalevee, X. Allonas, J. P. Fouassier, M. Shirai, and M. Tsunooka, Chem. Lett., 32, 178 (2003). 